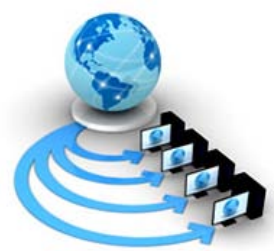

Volume 9, No. 2, March-April 2018

International Journal of Advanced Research in Computer Science

REVIEW ARTICLE

\author{
Available Online at www.ijarcs.info
}

\title{
LOAD BALANCING ALGORITHMS IN CLOUD COMPUTING ENVIRONMENT
}

\author{
Poonam \\ Department of Computer Science \\ Deenbandhu Chhotu Ram University of Science and \\ Technology \\ Murthal, India
}

\author{
Suman \\ Department of Computer Science \\ Deenbandhu Chhotu Ram University of Science and \\ Technology \\ Murthal, India
}

\author{
Sukhdip Singh \\ Department of Computer Science \\ Deenbandhu Chhotu Ram University of science and Technology \\ Murthal, India
}

\begin{abstract}
Cloud computing is a radical technology which provides computing as-a-service instead of providing computing as a product. It provisions computing resources on demand by paying for fraction of time we are using them. Concept of cloud reduces overall cost and management efforts through efficient utilization of various resources. Cloud computing has developed too much but still it has various research challenges like security, reliability, availability, load balancing, power management and data traffic analysis etc. which need researchers immediate attention. Load balancing is one of the hot research areas nowadays. It is the process of uniformly distributing workload on geographically distributed data centers. Load balancing algorithms provide the mechanism of adjusting load according to the application and node capacity. This paper focuses on load balancing, dynamic and static load balancing algorithms and future work in this direction.
\end{abstract}

Keywords: Cloud computing, Dynamic algorithms, Load balancing, Static algorithms

\section{INTRODUCTION}

The concept of cloud has brought a revolution over internet for executing different applications without spending too much on various resources. The concept was firstly introduced 1960's when IBM developed its mainframe computers. Cloud inherited various concepts from mainframe systems like consumption-based pricing model, virtual machines and multi-tenancy etc. and term cloud became popular in 2007. Cloud can be divided in frontend and backend. Frontend is made up of consumers of cloud and backend of cloud providers and cloud developers. Future of cloud is glorious and it is used almost in every area these days like transportation, healthcare, mobile computing, monitoring and education etc. [1] [2].

Cloud is used almost in everything from storage to processing. It provides opportunities to third parties and large or small business organizations to flourish their business without too much initial investment. For efficient working and response from cloud, it's important to balance load on nodes of cloud. Load balancing is the uniform distribution of load on the different nodes of cloud so that none of them gets overloaded or under loaded and we get good results by enhancing various parameters like response time, throughput, energy consumption and processing speed etc. [3] [4] Various types of load balancing techniques can be applied depending on application requirements like static, dynamic, hierarchical, distributed, and centralized etc. Dynamic algorithms are used widely as they consider current state of system, can work in distributed and heterogeneous environment.
This paper is organized as follows section 2 discusses important characteristics of cloud computing, section 3 discuss various load balancing algorithms and section 4 concludes the paper.

\section{CLOUD COMPUTING}

Cloud inherits features of various existing technologies like distributed computing, grid Computing, utility computing and autonomic computing etc. Main idea which makes cloud different from other technologies is virtualization through which multiple applications can be executed on a single server simultaneously [5].

\section{A. Features of Cloud}

Cloud provides various features which makes it different from other technologies. Some features shown in Fig. 1. are listed below.

- On-demand-services: cloud resources can be accessed by user at any time and in any amount.

- Broad access: services can be obtained from cloud at any time and at any place.

- Multitenant model: multi-tenancy means multiprogramming but on pay per use basis.

- Dignified services: Cloud can automatically optimize the resources provided by it.

- Scalable: More resources can be provisioned on demand as cloud environment is scalable. 


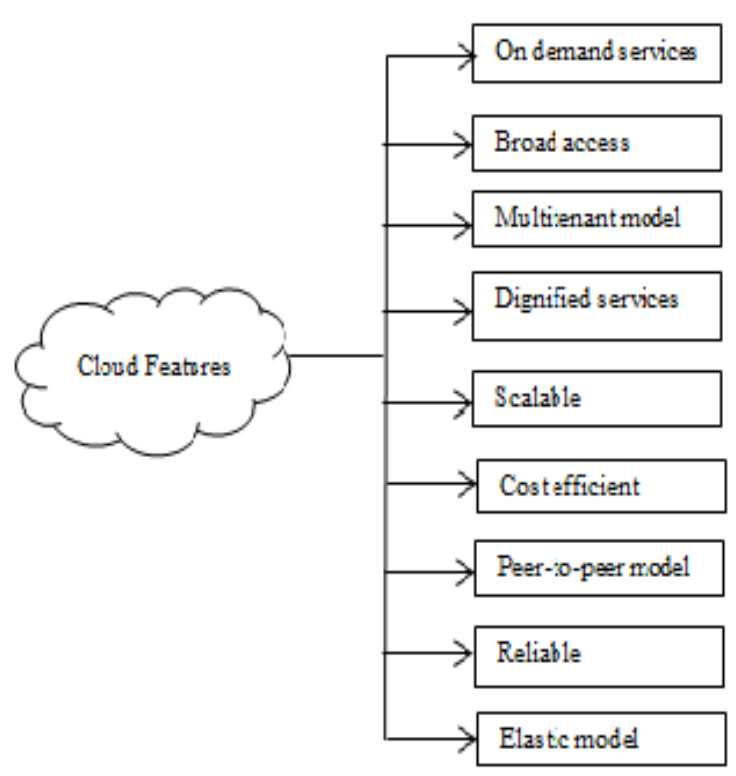

Fig. 1. Features of cloud.

- Cost efficient: This model reduces cost by providing shared access to resources in cloud. Cloud environment can be allocated and de-allocated depending on need. When demand decreases, these resources can be de-allocated which leads to significant decrease in cost.

- Peer-to-peer model: Cloud is made of distributed nodes without any central authority and all nodes (either service provider or service user) are at same level.

- Reliable: Cloud computing model is highly reliable as data is replicated on multiple nodes, if one node goes out of service other can handle its tasks.

- Elastic model: User can demand additional resources from cloud according to their requirement as cloud provides flexible environment.

\section{B. Cloud Services}

Three types of services are provided by cloud to its user software as a service, platform as a service and infrastructure as a service [6].

- Software as a service: This model provides different software which can be directly used by user without any concern about their infrastructure and implementation. Gmail, Facebook, Microsoft online are example Software as a service hosted over cloud [7].

- Platform as a service: This model provides platform for development of new applications. Google App Engine is widely used for developments of new apps without installation of any infrastructure. Other examples are Windows Azure and Heroku.

- Infrastructure as a service: This model provides resources to users like memory, processing, bandwidth on lease for processing of applications. Amazon Elastic Compute Cloud, Amazon simple storage service are examples of it.

\section{Deployment Models}

Four type of clouds are provided by cloud service providers depending on user's demand about different parameters like security, reliability etc. as in Fig.2. [8].

- Public cloud: This cloud is owned and managed by large organizations like Google, Microsoft etc. and available for general public. Public cloud is less secure because of its public access.

- Private cloud: Private cloud is secured one and exclusive for the use of a single organization. This cloud is costly as compared to public cloud.

- Community Cloud: This cloud is owned and managed by multiple organizations that have same working procedures. This is cost effective way of using cloud as cost is shared among organizations.

- Hybrid cloud: This cloud is combination of public, private and community cloud. This cloud is secure and more flexible as it combines benefits of all three clouds. Different types of cloud deployment models are listed in Table 1.
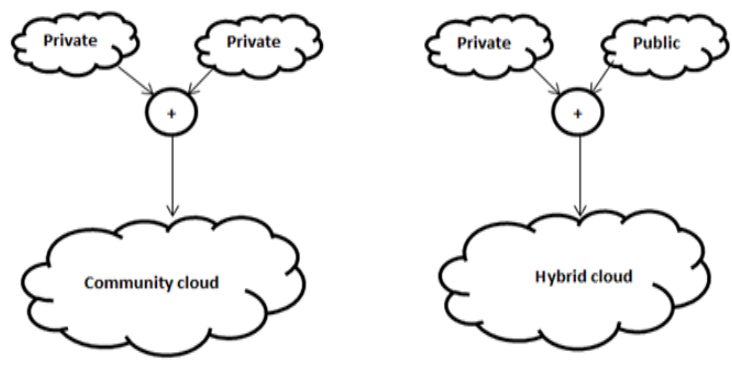

Fig. 2. Different Type of Cloud Models.

Table 1. Deployment models

\begin{tabular}{|c|c|c|c|}
\hline $\begin{array}{l}\text { Deployment } \\
\text { model }\end{array}$ & Advantage & Disadvantage & Example \\
\hline $\begin{array}{l}\text { Public } \\
\text { cloud }\end{array}$ & $\begin{array}{l}\text { Cost Effective, } \\
\text { High availability } \\
\text { and scalability }\end{array}$ & $\begin{array}{c}\text { Security and } \\
\text { privacy issues, } \\
\text { unreliability }\end{array}$ & $\begin{array}{c}\text { Amazon EC2, } \\
\text { Microsoft } \\
\text { Office 365, } \\
\text { IBM Smart } \\
\text { Cloud, } \\
\text { Microsoft } \\
\text { Windows } \\
\text { Azure }\end{array}$ \\
\hline $\begin{array}{l}\text { Private } \\
\text { cloud }\end{array}$ & High security & Costly & $\begin{array}{c}\text { Ubuntu } \\
\text { Enterprise } \\
\text { Cloud (UEC), } \\
\text { Eucalyptus, } \\
\text { Amazon VPC }\end{array}$ \\
\hline $\begin{array}{l}\text { Community } \\
\text { cloud }\end{array}$ & $\begin{array}{c}\text { Good for } \\
\text { organizations } \\
\text { having same } \\
\text { policies }\end{array}$ & $\begin{array}{c}\text { Costly as } \\
\text { compared to } \\
\text { public cloud }\end{array}$ & $\begin{array}{c}\text { Google Apps } \\
\text { for } \\
\text { Government, } \\
\text { Microsoft } \\
\text { Government } \\
\text { Community } \\
\text { Cloud }\end{array}$ \\
\hline $\begin{array}{l}\text { Hybrid } \\
\text { cloud }\end{array}$ & $\begin{array}{c}\text { Cost effective and } \\
\text { secure }\end{array}$ & $\begin{array}{c}\text { Privacy and } \\
\text { integrity issues }\end{array}$ & $\begin{array}{c}\text { Windows } \\
\text { Azure, } \\
\text { VMware cloud }\end{array}$ \\
\hline
\end{tabular}




\section{LOAD BALANCIING}

Cloud is made of large no of nodes or servers distributed geographically. Whenever a request arrives for processing of an application it needs to be distributed uniformly among servers of cloud without depleting its resources. This process of efficiently distributing load across servers without getting overloaded or under loaded is called load balancing [9][10]. Existing load balancing algorithms can be broadly classified into various categories like static, dynamic, centralized, distributed, hierarchical etc. [11][12]. Comparison between dynamic and static algorithms is shown in Table 2.

\section{A. Static Algorithms}

Static algorithms rely on history and don't consider present state of system. These algorithms are easy to implement and works for homogenous environments. These algorithms are obsolete now and not used much. Few of the static algorithms are compared in Table 3.

\section{B. Dynamic Algorithms}

These algorithms consider both present and previous state of system. They are fault tolerant and can handle busty traffic efficiently even in heterogeneous environments. These algorithms are used often for balancing load on cloud. But these algorithms incur high cost and take more execution time. Comparative analysis of important dynamic algorithms is presented in Table 4.

Table 2. Comparison of static and dynamic algorithms.

\begin{tabular}{|c|c|c|}
\hline Parameters & Static algorithms & Dynamic algorithms \\
\hline State & $\begin{array}{c}\text { Depends on previous } \\
\text { state }\end{array}$ & $\begin{array}{c}\text { Depends on previous as } \\
\text { well as present state }\end{array}$ \\
\hline Environment & Homogenous & Heterogeneous \\
\hline Load & Can't handle heavy load & Can handle heavy load \\
\hline Nature & Simple & Complex \\
\hline Fault tolerant & Not fault tolerant & Fault tolerant \\
\hline Example & FIFO, Round-Robin etc. & ACO, GA etc. \\
\hline
\end{tabular}

Table 3. Static algorithms

\begin{tabular}{|c|c|c|c|c|}
\hline S. no. & $\begin{array}{l}\text { Load balancing } \\
\text { approach }\end{array}$ & Objective & Merit & Demerit \\
\hline 1 & FIFO [13] & $\begin{array}{l}\text { Efficient and simple } \\
\text { algorithm }\end{array}$ & $\begin{array}{l}\text { Fair allocation based on } \\
\text { arrival time }\end{array}$ & Large response time \\
\hline 2 & Round-Robin [14] & $\begin{array}{c}\text { Uniform resource } \\
\text { utilization }\end{array}$ & Free from starvation & $\begin{array}{l}\text { Sometimes lead to load } \\
\text { imbalance }\end{array}$ \\
\hline 3 & $\begin{array}{l}\text { Weighted Round- } \\
\text { Robin [14] }\end{array}$ & $\begin{array}{l}\text { To improve RR } \\
\text { algorithm }\end{array}$ & $\begin{array}{l}\text { Better performance than } \\
\text { Round-Robin }\end{array}$ & $\begin{array}{l}\text { Execution time prediction is } \\
\text { required }\end{array}$ \\
\hline 4 & OLB [15] & $\begin{array}{l}\text { To utilize each node } \\
\text { efficiently }\end{array}$ & $\begin{array}{l}\text { Efficient resource } \\
\text { utilization }\end{array}$ & Large makespan \\
\hline 5 & $\begin{array}{l}\text { Minimum } \\
\text { Execution Time } \\
\text { [15] }\end{array}$ & $\begin{array}{l}\text { To execute jobs } \\
\text { speedily }\end{array}$ & Improved makespan & $\begin{array}{c}\text { May lead to load imbalance } \\
\text { as not considering current } \\
\text { state }\end{array}$ \\
\hline 6 & $\begin{array}{c}\text { Minimum } \\
\text { Completion Time } \\
\text { [15] }\end{array}$ & $\begin{array}{l}\text { To execute jobs } \\
\text { quickly }\end{array}$ & $\begin{array}{l}\text { Better than minimum } \\
\text { execution time } \\
\text { algorithm as it } \\
\text { considers load also }\end{array}$ & Large makespan \\
\hline 7 & LBMM [15] & $\begin{array}{l}\text { Take benefit of both } \\
\text { Min-Min and Max- } \\
\text { Min }\end{array}$ & $\begin{array}{c}\text { Increased resource } \\
\text { utilization }\end{array}$ & $\begin{array}{l}\text { Based on theoretical } \\
\text { concepts }\end{array}$ \\
\hline 8 & $\begin{array}{c}\text { OLB+LBMM } \\
{[15]}\end{array}$ & $\begin{array}{l}\text { To decrease } \\
\text { execution time and } \\
\text { storage cost }\end{array}$ & $\begin{array}{l}\text { Reduced execution } \\
\text { time as compared to } \\
\text { OLB and LBMM }\end{array}$ & Network management cost \\
\hline 9 & $\begin{array}{c}\text { MIN-MIN [16] } \\
\text { [17] }\end{array}$ & $\begin{array}{c}\text { To reduce } \\
\text { processing time }\end{array}$ & Better response time & May lead to starvation \\
\hline
\end{tabular}




\begin{tabular}{|c|c|c|c|c|}
\hline S. no. & $\begin{array}{c}\text { Load balancing } \\
\text { approach }\end{array}$ & Objective & Merit & Demerit \\
\hline 10 & $\begin{array}{c}\text { Max-Min } \\
{[16][17]}\end{array}$ & $\begin{array}{c}\text { To reduce } \\
\text { processing time }\end{array}$ & Reduced makespan & Poor load balancing \\
\hline
\end{tabular}

Table 4. Dynamic algorithms

\begin{tabular}{|c|c|c|c|c|}
\hline S. no. & $\begin{array}{l}\text { Load balancing } \\
\text { approach }\end{array}$ & Objective & Merit & Demerit \\
\hline 1 & $\begin{array}{l}\text { Biased Random } \\
\text { Sampling [18] }\end{array}$ & $\begin{array}{l}\text { To achieve load } \\
\text { balancing through } \\
\text { random sampling }\end{array}$ & $\begin{array}{l}\text { Good performance in } \\
\text { large networks }\end{array}$ & $\begin{array}{c}\text { Randomness may lead load } \\
\text { imbalance }\end{array}$ \\
\hline 2 & ACO [7], [19] & $\begin{array}{l}\text { To improve } \\
\text { computing power }\end{array}$ & $\begin{array}{l}\text { Efficiently balance the } \\
\text { load }\end{array}$ & May lead to stagnation \\
\hline 3 & GA [20] & $\begin{array}{l}\text { To minimize } \\
\text { makespan and cost }\end{array}$ & Improved performance & This may fall in local optima \\
\hline 4 & $\begin{array}{l}\text { Particle Swarm } \\
\text { Optimization } \\
\text { (PSO) [21] }\end{array}$ & $\begin{array}{l}\text { Better load } \\
\text { distribution }\end{array}$ & $\begin{array}{l}\text { Cost effective and } \\
\text { scalable algorithm }\end{array}$ & Poor convergence \\
\hline 5 & $\begin{array}{l}\text { Improved Particle } \\
\text { Swarm } \\
\text { Optimization } \\
\text { (IPSO) [22] }\end{array}$ & $\begin{array}{c}\text { To improve execution } \\
\text { time }\end{array}$ & $\begin{array}{l}\text { Reduced makespan } \\
\text { Elude local optima }\end{array}$ & Complex \\
\hline 6 & ALO [23] & $\begin{array}{c}\text { Reduce makespan and } \\
\text { improve completion } \\
\text { time }\end{array}$ & $\begin{array}{l}\text { High search space } \\
\text { exploration and } \\
\text { exploitation }\end{array}$ & $\begin{array}{l}\text { Required to test on different } \\
\text { scales of cloud }\end{array}$ \\
\hline 7 & $\begin{array}{l}\text { Cloud Light } \\
\text { Weight [24] }\end{array}$ & $\begin{array}{l}\text { Achieve load balance } \\
\text { without violating SLA }\end{array}$ & $\begin{array}{l}\text { Minimize migration time } \\
\text { and Scalable }\end{array}$ & Expensive approach \\
\hline 8 & $\begin{array}{l}\text { Honey Bee } \\
\text { Foraging [25] }\end{array}$ & $\begin{array}{c}\text { To meet dynamically } \\
\text { demands }\end{array}$ & $\begin{array}{l}\text { Good in heterogeneous } \\
\text { environments }\end{array}$ & $\begin{array}{l}\text { Poor improvement in } \\
\text { throughput }\end{array}$ \\
\hline 9 & Multi Cluster [10] & $\begin{array}{l}\text { Load balancing with } \\
\text { improved security }\end{array}$ & $\begin{array}{l}\text { Uniform load balancing } \\
\text { with high security }\end{array}$ & Complex approach \\
\hline 10 & $\begin{array}{l}\text { ESCE algorithm } \\
\text { [26] }\end{array}$ & $\begin{array}{l}\text { Allocation of VMs } \\
\text { on priority basis }\end{array}$ & $\begin{array}{l}\text { Unbiased distribution of } \\
\text { load }\end{array}$ & $\begin{array}{l}\text { Leads to central point of } \\
\text { failure }\end{array}$ \\
\hline
\end{tabular}

\section{CONCLUSION}

Use of cloud is ubiquitous and increasing at faster rate. Cloud is used nowadays in almost every area. Cloud computing technology has provided an opportunity for business organizations to flourish without making much investment in infrastructure. Due to ubiquitous use of cloud, data on cloud is increasing at exponential rate and it needs to be managed properly for efficient use of services. Load balancing techniques are used for uniform distribution of data so as to balance load on different servers. Millions of users are using cloud computing services and their number may increase in future. Increase in load on servers will lead to increase in response time resulting in user dissatisfaction and performance degradation. So by applying efficient load balancing technique for distributing user's requests uniformly over nodes of server, system performance and user's satisfaction can be increased significantly. This paper presented an analysis of static and dynamic load balancing algorithms on cloud. Dynamic algorithms are more efficient and used more frequently for handling runtime traffic as their decision is based on both current and previous state of system. Different algorithms consider different parameters like throughput, response time, bandwidth etc. for balancing the load on nodes of cloud. Future work will be oriented towards design of an efficient load balancing algorithm considering energy consumption, VM migration etc and combining best features of static and dynamic algorithms so as to provide cloud services efficiently and with ease in different environments.

\section{REFERENCES}

[1] Buyya, R., Yeo, C.S., Venugopal, S., Broberg, J. and Brandic, I., "Cloud computing and emerging IT platforms: Vision, hype, and reality for delivering computing as the 5th utility," 
Future Generation computer systems, vol. 25(6), pp.599-616, 2009.

[2] Mondal, B., Dasgupta, K. and Dutta, P., "Load balancing in cloud computing using stochastic hill climbing-a soft computing approach,” Procedia Technology, vol. 4, pp.783789, 2012.

[3] Singh, A., Juneja, D. and Malhotra, M., “Autonomous agent based load balancing algorithm in cloud computing," Procedia Computer Science, vol. 45, pp.832-841, 2015.

[4] Gupta, S. and Sanghwan, S., "Load balancing in cloud computing: A review," International Journal of Science, Engineering and Technology Research (IJSETR), vol. 4(6),2015.

[5] Sriram, Ilango, and Ali Khajeh-Hosseini, "Research agenda in cloud technologies," arXiv preprint arXiv:1001.3259, 2010.

[6] Alam, M.I., Pandey, M. and Rautaray, S.S., "A comprehensive survey on cloud computing," International Journal of Information Technology and Computer Science, vol. 2, pp.68-79,2015.

[7] Hayes, B., "Cloud computing," Communications of the ACM, vol. 51(7), pp.9-11, 2008.

[8] Zhang, Q., Cheng, L. and Boutaba, R., "Cloud computing: state-of-the-art and research challenges," Journal of internet services and applications, vol. 1(1), pp.7-18, 2010.

[9] Sangwan, S., Singh, P. and Patel, R.B., "Uivh-algorithm for seamless mobility in heterogeneous wireless network," In Proceedings of the CUBE international information technology conference (pp. 210-215). ACM, 2012.

[10] Sangwan, S. and Sangwan, S., "An Effective Approach on Scheduling Algorithm in Cloud Computing,” 2014.

[11] Roy, S., Bose, R. and Sarddar, D., "Fuzzy based dynamic load balancing scheme for efficient edge server selection in Cloudoriented content delivery network using Voronoi diagram,” In Advance Computing Conference (IACC), 2015 IEEE International (pp. 828-833),2015.

[12] Gandhi, R., Liu, H.H., Hu, Y.C., Lu, G., Padhye, J., Yuan, L. and Zhang, M., "Duet: Cloud scale load balancing with hardware and software," ACM SIGCOMM Computer Communication Review, vol. 44(4), pp.27-38,2015.

[13] Vibha M B, R.RajuGondkar, "Smart Load Balancing Algorithm towards Effective Cloud Computing,." International Journal of Advanced research in Computer and Communication Engineering, vol. 5(4) : 543-547, 2016.

[14] Tong, Ruixia, and Xiongfeng Zhu., "A load balancing strategy based on the combination of static and dynamic," In Database Technology and Applications (DBTA), 2010 2nd International Workshop on :1-4,2010.

[15] Wang, S.C., Yan, K.Q., Liao, W.P. and Wang, S.S., “Towards a load balancing in a three-level cloud computing network,"
In Computer Science and information technology (ICCSIT), 2010 3rd IEEE International Conference on (Vol. 1, pp. 108113). IEEE, 2010.

[16] Belkhouraf, M., Kartit, A., Ouahmane, H., Idrissi, H.K., Kartit, Z. and El Marraki, M., "A secured load balancing architecture for cloud computing based on multiple clusters," In Cloud Technologies and Applications (CloudTech), 2015 International Conference on (pp. 1-6). IEEE,2015

[17] Sran, N. and Kaur, N., "Comparative analysis of existing load balancing techniques in cloud computing," International Journal of Engineering Science Invention, vol. 2(1), pp.6063,2013.

[18] Rahmeh, O.A., Johnson, P. and Taleb-Bendiab, A., “A dynamic biased random sampling scheme for scalable and reliable grid networks,” INFOCOMP, vol. 7(4), pp.1-10,2008.

[19] Kaur, Davinder, and Sarpreet Singh., "An Efficient Job Scheduling Algorithm using Min-Min and Ant Colony Concept for Grid Computing," International Journal Of Engineering And Computer Science ,vol. 3(07 ), 2014.

[20] Dasgupta, K., Mandal, B., Dutta, P., Mandal, J.K. and Dam, S., "A genetic algorithm (ga) based load balancing strategy for cloud computing,” Procedia Technology, vol. 10, pp.340-347, 2013.

[21] Kaur, G. and Sharma, S., "Research Paper on Optimized Utilization of Resources Using PSO and Improved Particle Swarm Optimization (IPSO) Algorithms in Cloud Computing," International Journal of Advanced Research in Computer Science \& Technology (IJARCST 2014), vol. 2(3), 2014.

[22] Pan, K. and Chen, J., "September. Load balancing in cloud computing environment based on an improved particle swarm optimization,” In Software Engineering and Service Science (ICSESS), 2015 6th IEEE International Conference on (pp. 595-598). IEEE, 2015.

[23] Mirjalili, S., “The ant lion optimizer," Advances in Engineering Software, 83, pp.80-98, 2015.

[24] Mesbahi, M., Rahmani, A.M. and Chronopoulos, A.T., "Cloud light weight: A new solution for load balancing in cloud computing,” In Data Science \& Engineering (ICDSE), 2014 International Conference on (pp. 44-50). IEEE, 2014.

[25] Randles, M., Lamb, D. and Taleb-Bendiab, A., “A comparative study into distributed load balancing algorithms for cloud computing,” In Advanced Information Networking and Applications Workshops (WAINA), 2010 IEEE 24th International Conference on (pp. 551-556). IEEE, 2010.

[26] Suguna, S., and R. Barani., "Simulation of Dynamic Load Balancing Algorithms," Bonfring International Journal of Software Engineering and Soft Computing 5(1): 1, 2015. 